\title{
ANALISIS MANAJEMEN PENGELOLAAN PASAR TRADISIONAL GUNA MENINGKATKAN PENDAPATAN PEDAGANG KECIL (Studi Kasus Pasar KIRINGAN Desa Kemlagilor Turi Lamongan)
}

\author{
Luluk Nur Azizah \\ Prodi Manajemen, Fakultas Ekonomi, Universitas Islam Lamongan \\ Jl. Veteran No.53A Lamongan \\ Telp. ( 0322 ) 324706, Faks. ( 0322 ) 324706 \\ Email :jpim@unisla.ac.id
}

\begin{abstract}
ABSTRAK
Pasar Tradisional adalah salah satu sarana pendukung untuk pemenuhan kebutuhan masyarakat. pasar akan maju apabila pengelolaannya berjalan dengan baik, namun sebaliknya jika pengelolaan tidak berjalan dengan baik maka akan mengakibatkan kerugian, baik dalam pasar tersebut ataupun bagi mitra kerjanya. Pasar KIRINGAN merupakan pasar yang cukup terkenal di kecematan Turi kab Lamongan, namun pengelolaan di pasar tradisional KIRINGAN tergolong kurang baik. Penelitian ini dilakukan di Pasar Tradisional KIRINGAN Desa Kemlagilor Turi Lamongan bertujuan untuk mengetahui bagaimana manajemen pengelolaan di Pasar KIRINGAN dan apakah manajemen pengelolaan tersebut memiliki pengaruh terhadap pendapatan pedagang kecil mengenai manajemen pengelolaan Pasar KIRINGAN Desa Kemlagilor Turi Lamongan.

Populasi yang digunakan dalam penelitian sebanyak 200 orang, serta sampelnya dipilih berdasarkan metode persentase, dengan taraf persentase sebesar $20 \%$ sehingga sampelnya sebanyak 40 orang yaitu 3 dari aparatur Desa, 37 dari pedagang pasar KIRINGAN. Dari analisis yang telah dilakukan diperoleh hasil penelitian yang menyatakan bahwa manajemen pengelolaan Pasar Tradisional KIRINGAN tergolong kurang baik jika dilihat dari aspek penyediaan infrastruktur, perbaikan sarana dan prasarana Pengelolaan yang kurang baik menimbulkan pengaruh terhadap pendapatan pedagang kecil.
\end{abstract}

Kata Kunci : Manajemen Pengelolaan, Pasar Tradisional, Pendapatan 


\section{PENDAHULUAN}

Pasar pada dasarnya akan melibatkan dua subyek pokok, yaitu produsen dan konsumen. Kedua subyek tersebut masing- masing mempunyai peranan yang sangat besar terhadap pembentukan harga barang yang ada di pasar. Hal ini didasari atau didorong oleh faktor perkembangan ekonomi yang awalnya hanya bersumber pada problem untuk memenuhi kebutuhan hidup (kebutuhan pokok).

Dalam sistem ekonomi, pasar mempunyai fungsi-fungsinya sendiri, yang mana dalam fungsi tersebut bertujuan untuk memuaskan perekonomian pasar. Semua fungsi tersebut haruslah meyakinkan setiap orang bahwa pasar dapat memecahkan berbagai masalah. Jadi dalam hal ini beberapa ekonom percaya bahwa ekonomi dalam pasar bekerja dengan efisien dan mereka juga percaya bahwa pasar dapat melaksanakan fungsinya dengan memuaskan, tetapi terkadang pasar juga masih membutuhkan adanya campur tangan pemerintah dalam mekanisme pasar, karena dengan adanya campur tangan pemerintah maka kesejahteraan masyarakat akan terpenuhi.

Agar pasar berjalan dengan seimbang maka diperlukan sebuah manajemen pengelolaan didalamnya. Manajemen pengelolaan dimaksudkan agar terciptanya pasar yang dapat mensejahterakan pedagangnya tanpa ada kecurangan- kecurangan didalamnya. Pasar tradisional yang berjalan sendiri tanpa ada yang mengontrol, ternyata telah menyebabkan banyak permasalahan.

Manajemen melibatkan aktivitasaktivitas koordinasi dan pengawasan terhadap pekerjaan orang lain, sehingga perkerjaan tersebut dapat diselesaikan secara efisien dan efektif. Fungsi-fungsi manajemen antara lain perencanaan (planning), pengorganisasian (organizing), penggerakan (actating), pengendalian (controlling).

Berdasarkan manajemen pengelolaan, pasar dibagi menjadi dua yaitu pasar tradisional dan pasar modern. Pasar tradisional sebagai pasar yang dibangun dan dikelola oleh Pemerintah, Pemerintah Daerah, Swasta, Badan Usaha Milik Negara, dan Badan Usaha Milik Daerah termasuk kerjasama dengan swasta dengan tempat usaha berupa toko, kios, los, dan tenda yang dimilki/ dikelola oleh pedagang kecil, menengah, swadaya masyarakat, atau koperasi dengan usaha skal kecil, menegah, dengan usaha skala kecil, modal kecil dan dengan proses jual beli barang dagangan melalui tawar menawar.

Keberadaan pasar khususnya pasar tradisional, merupakan salah satu indikator paling nyata kegiatan ekonomi masyarakat disuatu wilayah. Kegiatan 
pasar tradisional digambarkan dengan kesibukan yang padat dengan kegiatan tawar menawar di sana-sini. Kegiatan tawar menawar yang ramai ini menjadi salah satu ciri khas pasar tradisional.

Adapun permasalahan terkait pengelolaan pasar tradisional antara lain : (1) permasalahan dan citra negatif pasar tradisional umumnya terjadi akibat kurang disiplinnya pedagang, pengelola pasar yang tidak profesional, dan tidak tegas dalam menerapkan kebijakan atau aturan terkait pengelolaan operasional pasar, (2) masalah internal pasar seperti buruknya manajemen pasar, sarana dan prasarana pasar yang sangat minim, menjamurnya para pedagang kaki lima yang mengurangi pendapatatan pedagang, dan minimnya bantuan permodalan yang tersedia bagi pedagang tradisional. Pengelolaan pasar yang baik dan profesional diharapkan dapat meningkatkan daya saing pasar tradisonal, meningkatkan keuntungan serta dapat menjamin kelangsungan dari pasar itu sendiri.

Pasar tradisional yang ditemui sekarang pada umumnya dapat hidup berdampingan dengan perdagangan yang dikelola dengan lebih modern, seperti kios dan toko. Adapun susunannya biasanya di tengah pasar terdiri dari los yang memanjang tempat pedagang meletakkan dagangannya. Di antara los terdapat gang tempat orang-orang berjalan melihat-lihat dan mencari berbagai barang- barang kebutuhan yang diinginkan. Biasanya sisi tepinya juga dipenuhi oleh para pedagang yang menggelar dagangannya di atas tampah yang ditaruh di atas tenggok (bakul), sehingga jumlah dan jenis dagangannya relatif sedikit (misalnya penjual tahu, tempe, Gorengan, sembako dan sayur-mayur).

Munculnya pedagang- pedagang baru di luar pasar dengan barang dagangan yang sama dengan di dalam pasar, membuat pembeli enggan masuk ke dalam pasar karena mereka bisa mendapatkan barang di luar pasar dengan kualitas dan harga yang kurang lebih sama. Keadaan semacam ini menimbulkan masalah baru bagi pengelola pasar, karena pasar tumpah ke badan-badan jalan menimbulkan berkurangnya pendapatan para pedagang yang berlokasi didalam pasar dan kurang tertibnya para pedagang yang berjualan dibahu jalan.

Berdasarkan penjelasan yang telah diuraikan diatas, maka peneliti merasa tertarik melakukan penelitian lapangan mengenai : "Analisis Manajemen Pengelolaan Pasar Tradisional Guna Meningkatkan Pendapatan Pedagang Kecil (Studi Kasus Pasar KIRINGAN Desa Kemlagilor Turi Lamongan).

\section{Rumusan Masalah}


Bagaimana Manajemen Pengelolaan Pasar Tradisional KIRINGAN di

Desa Kemlagilor Turi Lamongan?

\section{LANDASAN TEORI}

\section{A. Manajemen}

1. Pengertian Manajemen Manajemen menurut Parker (Stoner \& Freeman) yang ditulis oleh Husaini Usman adalah seni melaksanakan pekerjaan melalui orang-orang (the art of getting things done throgh people). Manajemen dalam arti luas adalah perencanaan, pelaksanaan dan pengawasan (P3) sumber daya organisasi untuk mencapai tujuan secara efektif dan efisien. Manajemen dalam arti sempit adalah manajemen sekolah/madrasah, yang meliputi manajemen perencanaan program sekolah/madrasah. Manajemen yang mengatur jalannya suatu proses dalam mencapai suatu tujuan tentulah memiliki fungsi-fungsi yang bertujuan supaya sistematika urutan pembahasannya lebih teratur, lebih mudah dan lebih mendalam.

Fungsi-fungsi manajemen antara lain:
a. Planning
b. Organizing
c. Stafing
d. Motivation
e. Controling

2. Manajemen Pengelolaan

Manajemen pengelolaan adalah hal yang dilakukan oleh para manajer. Manajemen melibatkan aktivitasaktivitas koordinasi dan pengawasan terhadap pekerjaan orang lain, sehingga perkerjaan tersebut dapat diselesaikan secara efisien dan efektif. Berdasarkan manajemen pengelolaan, pasar dibagi menjadi dua yaitu pasar tradisional dan pasar modern.

3. Prinsip-Prinsip Manajemen Pengelolaan
a. Prinsip efisiensi dan efektifitas
b. Prinsip pengelolaan
c. Prinsip pengutamaan tugas pengelolaan
d. Prinsip kepemimpinan yang efektif
e. Prinsip kerja sama
f. Manajemen pasar tradisional

\section{B. Konsep Pedagang Kecil}

1. Pengertian Pedagang Kecil Pedagang adalah orang yang melakukan perdagangan, memperjualbelikan barang yang tidak diproduksi sendiri untuk memperoleh suatu keuntungan. Sedangkan pedagang kecil adalah orang yang dengan modal yang relatif sedikit melaksanakan aktifitas produksi dalam arti luas (produksi barang, menjual barang dan menyelenggarakan jasa) 


untuk memenuhi kebutuhan
kelompok konsumen tertentu
dalam masyarakat usaha yang
mana dilaksanakan ditempat-
tempat yang dianggap strategis
dan ekonomis dalam suasana
lingkungan yang informal."

2. Indikator Pedagang Kecil

Adapun indikator pedagang kecil antara lain :
a. Kemampuan pedagang kaki lima dalam menyewa ruko
b. Pendapatan yang dihasilkan
c. Sumber modal
d. Jumlah tanggungan

\section{Konsep Pendapatan}

1. Setiap orang memiliki pendapatan yang berbeda, penghasilan seseorang tergantung dari penawaran dan permintaan untuk kerja orang tersebut, yang pada gilirannya tergantung dari kemampuan alami, modal manusia, diferensial kompensasi, diskriminasi, dan seterusnya Faktor-faktor yang Mempengaruhi Pendapatan Pedagang kecil Walaupun secara fisik pasar dibangun dengan baik, manfaat ekonomi bagi masyarakat sangat tergantung dengan penggunaan pasar. ada banyak faktor yang mempengaruhi pendapatan pedagang di pasar, antara lain:
a. Manajemen pasar
b. Los dan kios
c. Ongkos
d. Penjualan
e. Pembelian
f. Komoditi yang dijual
g. Khusus pasar hewan
h. Khusus pelelangan ikan
j. Hari operasional tempat
i. Jam operasional

\section{Konsep Pasar}

1. Pengertian pasar

Pasar adalah suatu tempat atau proses interaksi antara permintaan (pembeli) dan penawaran (penjual) dari suatu barang/jasa tertentu, sehingga akhirnya dapat menetapkan harga keseimbanagan (harga pasar) dan jumlah yang diperdagangkan. Jadi setiap proses yang mempertemukan antara pembeli dan penjual, maka akan membentuk harga yang disepakati antara pembeli dan penjual.

2. Pasar Tradisional

Pasar tradisional adalah tempat bertemunya penjual dan pembeli serta ditandai dengan adanya transaksi penjual pembeli secara langsung dan biasanya ada proses tawar menawar, bangunan biasanya terdiri dari kios-kios ata gerai, los dan dasaran 
terbuka yang dibuka oleh penjual maupun suatu pengelola pasar. kebayakan menjual kebutuhan sehari-hari, seperti bahan-bahan makanan berupa ikan, buah, sayursayuran, telur, daging, kain, pakaian, barang elektronik, ada, dll. Selain itu, ada pula yang menjual kue-kue dan barangbarang lainnya.

\section{ANALISIS DATA}

\section{A. Populasi dan Sampel}

Populasi adalah jumlah total dari keseluruhan unsur yang diteliti. Populasi dalam penelitian ini adalah seluruh pedagang pasar tradisional yang berjumlah 200 orang. Sampel adalah sebagian atau wakil populasi yang di teliti, untuk menentukan jumlah sampel digunakan rumus slovin dari 200 populasi dan batas toleransi eror $20 \%$ didapatkan hasil 40 sampel yang diambil secara acak.

B. Manajemen Pengelolan Pasar Tradisional di Pasar Kiringan, Desa

\section{Kemlagilor Turi Lamongan}

Di lihat dari prinsip-prinsip manajemen pengelolaan pasar tradisonal KIRINGAN, adalah sebagai berikut :

1. Prinsip efisiensi dan efektifitas

Efisiensi dan efektifitas merupakan bagian dari prinsip- prinsip manajemen. Titik tolak pelaksanaan manajemen dalam organisasi semaksimal mungkin memanfaatkan semua sumber, tenaga, dana dan fasilitas yang ada secara efisien. Fungsi-fungsi manajemen dioprasionalisasikan dengan mempertimbangkan sarana dan prasarana yang seirama dengan keadaan dan kemampuan organisasi,

2. Prinsip pengelolaan

Prinsip pengelolaan didasarkan pada langkah-langkah manajemen yang fungsional, yaitu merencanakan, mengorganisasikan, mengarahkan dan mengkontrol. Dengan demikian target yang dituju dengan mudah dapat dicapai dengan baik.

3. Prinsip kepemimpinan yang efektif Prinsip pemimpinan yang efektif harus memiliki kebijaksanaan dalam mengambil keputusan, tidak bertele-tele dan menghemat waktu, artinya tegas, lugas, tuntas dan berkualitas. Ia wajib mengembangkan hubungan baik dengan semua bawahannya, cerdas merealisasikan human relationship. Manajer yang baik adalah manajer yang tidak menyalahkan bawahan, tetapi mengingatkan dan menyarankan. 
Demikian juga bawahan yang baik tidak pernah menggugat kepada atasan, tetapi meluruskan dan menyadarkan sepanjang masih dalam konteks profesionalitas yang ada diatas aturan yang disepakati.

Dari hasil penelitian yang didapat prinsip kepemimpinan belum berjalan dengan baik di pasar tradisional KIRINGAN, karena pemimpin pasar KIRINGAN belum menjalankan tugasnya secara tegas dalam pengatur para pedagang untuk menyewa los atau kios yang masih kosong di dalam pasar.

Berdasarkan faktor-faktor manajemen pengelolaan diatas masih belum terealisasi di pasar tradisional KIRINGAN, inisiatif dari pihak pengelola pasar tentunya sangat diperlukan yaitu dengan mengatur atau mentata para pedagang untuk menyewa los atau kios yang masih kosong didalam pasar namun hal itu hanyalah keinginan para pedagang yang telah menyewa semata dan belum terealisasi.

Hal tersebut juga berpengaruh terhadap pendapatan para pedagang yang berjualan di dalam pasar KIRINGAN, seperti yang tertera dalam tabel di bawah ini :

\section{Tabel 4.1}

\begin{tabular}{|r|l|l|l|}
$\mathbf{N}$ & Jenis & Pendapatan & Pendapatan \\
o. & Los/Kios & Sebelum & Sesudah \\
1. & Los Tertutup & Rp 200.000/hari & Rp 150.000/hari \\
\hline 2 & Los Sayuran & Rp 100.000/hari & Rp 50.000/hari \\
\hline 3 & Los Ikan & Rp 150.000/hari & Rp 120.000/hari \\
\hline
\end{tabular}

Pendapatan Pedagang

Sumber data diperoleh dari hasil wawancara dengan beberapa pedagang,

Berdasarkan dari tabel diatas jumlah pedagang yang banyak berpengaruh dengan adanya pedagang yang berjualan dibahu jalan adalah para pedagang los tertutup/los sembako, los sayuran dan los ikan. Rata-rata para pedagang mengalami penurunan pendapatan sebesar $10-50 \%$ per harinya.

Untuk itu sudah sepantasnya pihak pengelola Pasar Tradisional KIRINGAN, Desa Kemlagilor Turi Lamongan menyediakan tempat berjualan yang layak demi terciptanya suasana yang nyaman bagi pedagang dan pembeli, disisi lain juga mempu menciptakan suasana yang kondusif antar pedagang agar semua proses dan prinsip-prinsip dalam manajemen pengelolaan dapat berjalan dengan baik. Jika hal tersebut telah terealisasi maka kondisi pasar akan terlihat rapi dan nyaman tidak seperti saat 
ini yang caruk-maruk serta terlihat semerawut.

\section{PENUTUP}

\section{A. Kesimpulan}

Berdasarkan pembahasan dan analisis, maka dapat diambil kesimpulan sebagai berikut : Pengelola pasar tradisional KIRINGAN Desa Kemlagilor Turi Lamongan, belum menunjukkan adanya manajemen pengelolaan yang baik, hal tersebut dapat dilihat dari (1) sarana dan prasarana seperti atap yang bocor, WC umum yang tidak terawat, kondisi tempat berjualan yang kurang memadai untuk para pedagang (2) belum mampu menciptakan suasana nyaman bagi para konsumen dan pembeli. Daya saing Pasar KIRINGAN sering terjadi adanya praktek-praktek kecurangan seperti padagang baru yang berjualan di bahu jalan, pengelola pasar tradisional membiarkan saja tanpa ada penanganan yang tegas, pengelola pasar hanya memberikan teguranteguran tanpa sanksi yang berat. Hal tersebut tentu akan berpengaruh terhadap pendapatan pedagang yang berjualan di dalam pasar.

\section{B. Saran-Saran}

Diharapkan pengelola pasar KIRINGAN Desa Kemlagi lor Turi Lamongan Tengah lebih meningkatkan kinerjanya secara menyeluruh dalam segala aspek sehingga dapat mengantisipasi segala kecurangan- kecurangan dan ketidak adilan yang terjadi di pasar KIRINGAN Desa Kemlagilor Turi Lamongan. Inisiatif dari pihak pengelola pasar tentunya sangat diperlukan yaitu dengan mengatur atau mentata para pedagang untuk menyewa los atau kios yang masih kosong didalam pasar.

\section{DAFTAR PUSTAKA}

Djam'an Santori dan Aan Komariah, 2009,Metode Penelitian Kualitatif Bandung: Alfabeta

Fahri Hamzah, 2010, Negara, Pasar Dan Rakyat, Jakarta: Yayasan Faham Indonesia

Gregory Mankiw, 2000, Pengantar Ekonomi Jilid 2, Jakarta, Erlangga

George R. Terry, 2013, Dasar-Dasar Manajemen, Jakarta:PT Bumi Aksara

Jhonatan Sarwono, 2006,Metode Penelitian Kuantitatif dan Kualitatif, Yogyakarta: Graha Ilmu

Joko Subagyo, 2006,Metode Penelitian (dalam teori dan praktek), Jakarta: PT. Asdi Mahasatya, cetakan kelima Kasmir, 2006, Kewirausahaan, Jakarta: PT. Raja Grafindo Persada

M. Arif Hakim, 2015, Peran Pemerintah Dalam Mengawasi Mekanisme Pasar Dalam Perspektif Islam, Stain 
Kudus, Penelitian Ilmiah Iqtishadia, Vol 8, No. 1 Malayu S.P

Nahdliyul Izza, 2011, Pengaruh Pasar Modern Terhadap Perdagangan Peraturan Menteri Dalam Negeri Republik Indonesia Nomor 20 Tahun 2012

Tentang Pengelolaan Dan Pemberdayaan Pasar Tradisioanal

Satria, 2010, Pasar Modern Dan Pasar

Tradisional, Jakarta: Rineka Cipta

Siswanto, 2012, Pengantar Akuntansi, Jakarta: Pt Bumi Aksara
Hasibuan, 2005, Manajemen Dasar, Pengertian dan Masalah, Jakarta: PT Toko Gunung

Pasar Tradisional, Yogyakarta: UIN Sunan Kalijaga

Philip Kotler \& A.B Susanto, 2000, Manajemen Pemasaran Di Indonesia analisis, Perencanaan, Implementasi Dan Pengendalian Jakarta: Salemba Empat, buku 1. 